\title{
THE INFLUENCE OF CHARISMATIC LEADERSHIP AND TRAINING ON THE PERFORMANCE OF THE INDONESIAN NAVY HYDROGRAPHIC AND OCEANOGRAPHIC CENTER WITH SELF EFFICACY AS AN INTERVENING VARIABLE
}

\author{
Indra Dermawan \\ Faculty of Economics, Universitas Negeri Jakarta \\ Jakarta, Indonesia \\ indradermawan7478@gmail.com
}

\begin{abstract}
The leadership in the TNI environment is very typical according to the stylish nature of the command organization and is supported by the participation of its members; therefore, this study aims to find out how the influence of charismatic leadership and training on the performance of the Indonesian Navy Hydrographic and Oceanographic Center (Pushidrosal) with Self Efficacy as intervening. This study was conducted on Pushidrosal personnel rank of officers, where the sample used was 217 respondents taken using the census method. Data obtained by questionnaire using a Likert scale to measure 45 indicators processed with Structural Equation Modeling (SEM) using the Amos 22.0 application.

The results showed that: Charismatic leadership and training had no direct effect on self-efficacy, self-efficacy had no direct effect on performance. Charismatic leadership and training have a significant positive effect on performance both directly and indirectly. The results of the study also show that Self Efficacy has a positive mediating role for charismatic leadership and training on performance.
\end{abstract}

Keywords: Charismatic Leadership, Training, Self Efficacy, Pushidrosal Performance

\section{INTRODUCTION}


The Indonesian Navy Hydrographic And Oceanographic Center (Pushidrosal), as one of the Development Councils within the Indonesian Navy, as described in Presidential Decree No. 62 of 2016 concerning the Composition of the Indonesian National Armed Forces Organization (Article 109), is tasked with organizing the development of hydrooceanography (hydros) which includes surveys, research, marine mapping, publications, application of the marine environment and navigation safety for both the military and public interests.

Staff personnel explained that there were still members whose performance was not optimal. This is indicated by the fact that there is still personnel when working hours do not use time optimally to work. The achievement of performance following the product and the results of the completion of low performance and, in fact, experience ups and downs (fluctuations). This explanation is supported by the product data below:

Table 1. Absorption Budget of The Indonesian Navy Hydrographic and Oceanographic Center

\begin{tabular}{|c|c|c|c|c|}
\hline \multirow{2}{*}{ No } & \multirow{2}{*}{ Year } & \multicolumn{3}{|c|}{ Type of activity } \\
\cline { 3 - 5 } & & State Budget & RM & PNBP \\
\hline $\mathbf{1}$ & $\mathbf{2}$ & $\mathbf{3}$ & $\mathbf{4}$ & $\mathbf{5}$ \\
\hline 1 & $\mathbf{2 0 1 7}$ & $99.78 \%$ & $99.10 \%$ & $98.04 \%$ \\
\hline 2 & $\mathbf{2 0 1 8}$ & $99.33 \%$ & $100.05 \%$ & $97.85 \%$ \\
\hline
\end{tabular}

The results of staff interview from The Indonesian Navy Hydrographic And Oceanographic Center of the Navy showed that the performance of members of The Indonesian Navy Hydrographic And Oceanographic Center of the Navy can still be improved with the support of the leader's role. With a new leader, a new leadership style will be followed as well. Soldiers need adaptation to the new leader to the fluctuations in soldiers' performance of The Indonesian Navy Hydrographic And Oceanographic Center. Leaders are individuals who help others to achieve their goals (Kreitner \& Kincki, 2014). In addition to the change of leadership, The Indonesian Navy Hydrographic And Oceanographic Center of the Navy also conducts various training sessions for soldiers. Automatic training is a factor that affects the performance of The Indonesian Navy 
Hydrographic And Oceanographic Center soldiers. Because with so much training, the soldiers will be more skilled in carrying out their duties. The organization's training program is one way that can improve each individual's performance (Jehanzeb \& Ahmed Bashir, 2013).

Another factor affecting the performance of The Indonesian Navy Hydrographic And Oceanographic Center soldiers is self-efficacy. The change of leadership and training undertaken will affect the soldiers' confidence to carry out the assigned tasks. Selfefficacy is very much needed in developing soldier performance because self-efficacy in soldiers will lead to confidence in his ability to promptly complete the work given by his supervisor. Self-efficacy becomes more involved in their tasks and then, in turn, improves performance, which increases the efficacy even further. Changes in self-efficacy over time are related to creative performance changes (Robbins \& Judge, 2013).

\section{LITERATURE REVIEW}

\section{The Performance}

Performance is a complex system; therefore, performance is regulated using a performance management system to be well controlled and assess what kind of employee performance in an organization (Decramer et al., 2013). Performance assessment is the result of an employee within the scope of their responsibilities (Veithzal, Mansyur, Thoby, \& Willy, 2014). Improved employee performance can be done with a 360-degree feedback performance assessment. 360-degree feedback is a performance management system where employees receive performance feedback from all organization leaders: supervisors, coworkers, self, and subordinates (Griffin \& Moorhead, 2013).

According to Bernardin and Russel (2003), to measure the performance of employees can use multiple dimensions of work, among others:

(1) Quantity. (2) Quality. (3) Timeliness (4) Cost-effectiveness. (5) Interpersonal impact. From the description above, it can be synthesized that performance is behavioral, incidental, measurable, and multifaceted displayed by each individual as an achievement generated within the scope of their responsibilities.

\section{Charismatic Leadership}


An organization needs strong leaders to run the organization effectively (Robbins \& Judge, 2013). Many types of leadership applied by a leader, but according to Achua and Lussier (2010), charismatic or transformational leadership is a leadership style that has an extraordinary influence on its members.

Humphreys (2002) explains the ability of charismatic leaders to change the value system of subordinates in order to achieve the goals obtained by developing one factor or all factors that are dimensions of transformational leadership, namely: ideal influence (idealized influence), inspiration (inspirational motivation), intellectual development (intellectual stimulation ) and personal attention (individualized consideration).

From the description above, it can be synthesized that charismatic leadership is the confidence of a leader where they genuinely believe in their assessment and abilities and the process of influencing individual and group activities.

\section{Self Efficacy}

Self-efficacy is defined as the belief that a person has the abilities needed to carry out the behavior needed for a task's success (Colquit, LePine \& Wesson, 2015). Meanwhile, according to Self-efficacy, which is defined as the belief that someone can perform adequately in certain situations (James et al., 2012).

Bandura (1997) divides the dimensions of self-efficacy into three dimensions, namely: (1) the level or magnitude dimension refers to the level of difficulty of the task that individuals believe will be able to overcome it, (2) Dimensi generality is that individuals may judge themselves to feel confident through various - in the activities or the surau of certain function areas, and (3) The stress dimension is related to the strength of one's self-efficacy when dealing with the demands of a task or a problem.

From the description above, it can be synthesized that self-efficacy is an individual's belief in facing and solving problems faced in various situations and able to determine actions in completing specific tasks and problems so that the individual can overcome obstacles and achieve the expected goals.

\section{Training}

Training is an activity carried out by an organization that is very important for employees where management can act to move employees explicitly or implicitly (Towler, Watson, \& Surface, 2014). Training is an activity carried out by an organization that is very 
important for employees where management can act to move employees explicitly or implicitly (Towler, Watson, \& Surface, 2014).

The training dimensions, according to Vietzhal Rivai (2005), include:

a. Training materials

By knowing the need for training, the training material that can be given can be determined as a result of the first step.

b. Training Method

Following the training material provided, then the most appropriate method or method of presentation is determined. The determination or selection of training methods is based on the material to be presented.

c. Trainer (Instructor)

The trainer must be based on his expertise and ability to transform those skills with the trainees.

d. Training Participants

In order for the training program to reach the target, participants should be selected who are truly "ready to be trained," meaning those workers who are included in the training are those who have been mentally prepared to join the program. In this step, it must always be maintained so that the implementation of training activities follows the specified program.

e. Training Facilities

Supporting tools Training evaluation is intended to measure the strengths of a program, its completeness, and the conditions that are feedback to assess or produce an appropriate output.

From the description above, it can be synthesized that training is an activity where employees get a transfer of learning information that is skills, abilities, and knowledge about how they will show a positive reaction to their task, and also they get an orientation about the culture of behavior that applies to an organization.

\section{Charismatic Leadership and Self Efficacy}

Charismatic leadership is the ability to influence, inspire, and direct individuals or groups' actions to achieve the desired goals. One of the characteristics of charismatic leaders 
evident in the literature is leaders' ability to improve employee self-efficacy (Thorlakton \& Murray, 1996).

Steven L. McShane, Mary Ann Von Glinow (2010) said, " self-efficacy a person belief that he or she has the ability motivation, correct role perceptions and favorable situations to complete a task successfully. " One's self-efficacy is the belief that he has the ability motivation, correct role perception, and a favorable situation to complete the task successfully.

Pillai and Williams (2004) research results show that leaders have an essential role to increase individual self-efficacy. Organizational leaders or direct superiors can provide motivation, direction, verbal persuasion, and reinforcement to individuals in carrying out certain activities and jobs to increase individual self-efficacy.

The research results were conducted by Harjono, Bode, and Victor (2015) entitled " The Effect Of Transformational Leadership And Self Efficacy To Performance Of Employees In PT. Air Manado. " The results showed that transformational leadership and selfefficacy had positive and significant effects on employee performance both simultaneously and partially. The management of PT Air Manado should continue to pay attention to the transformational leadership of the leader and the subordinates' selfefficacy to continue improving employee performance and achieving a goal more than expected.

Research conducted by Wahyuningsih (2015) with the title "The Effect of Transformational Leadership and Self Efficacy on Motivation of Public Elementary School Teachers in Kramat Jati District, East Jakarta" concluded that transformational leadership has a direct positive effect on self-efficacy. This means that the suitability of the principal's style in leading schools influences the self-efficacy of state elementary school teachers in the Kramat Jati District, East Jakarta

Based on the theory and logic of the results of previous studies, alternative hypotheses can be formulated:

H1: Charismatic leadership influences self efficacy

\section{Training and Self Efficacy}

Marilyn (1989) examined the effect of two training methods on self-efficacy and performance during training for creative problem-solving. The training method, which 
consists of cognitive modeling with exercises and reinforcement, results in a much higher self-efficacy than methods that involve lectures and practice alone. Participants in modeling training significantly outperform those in lecture conditions on the quantity and divergence of ideas generated.

Research conducted by Suseno (2009) entitled "The effect of interpersonal communication on self- efficacy as a trainer on students" uses the experimental method, with the experimental design of the pretest-posttest control group (pretest-posttest control group design). Conclude that training can improve self-efficacy.

Research conducted by Wardani (2012) aims to determine whether there are differences in practical communication training to improve student self-efficacy. The subjects of this study were students of the Faculty of Psychology, Airlangga University class of 2011. The number of subjects in this study was 15 people, nine consisting of male subjects and six female subjects-data collection tools used in the form of a soft skill self-efficacy questionnaire consisting of 47 items. Analysis of the data used in this study is the statistical test Paired T-test with the SPSS version 17.0 program's help. The results of the analysis of the data obtained show the provision of Effective Communication Training to Improve Student Self Efficacy.

Using a measure of self-efficacy internet developed in a longitudinal study, Torkzadeh and van Dyke (2002) investigated the effects of internet training on self-efficacy internet learners with a measure of self-efficacy before and after the training course. They show that training significantly increases the level of application-specific self-efficacy when trainees use information obtained during the course to assess the ability to perform tasks related to the domain.

The learning process in this training will increase individual self-efficacy and can trigger the realization of training transfer. The results of Tai's research (2006) show that contextual factors such as practical training can increase individual self-efficacy. On the other hand, self-efficacy can also increase if individuals get support from others (verbal persuasion). In the context of training, individual self-efficacy to transfer the training results that they follow will increase if they receive support from their direct supervisor and organizational management. 
Based on the theory and logic of the results of previous studies, alternative hypotheses can be formulated:

$\mathrm{H} 2$ : Training has an effect on self efficacy

\section{Charismatic Leadership and Performance}

A leader is task-oriented or employee-oriented. Leadership style is positively associated with leader effectiveness, but differences are often seen only at the level of each style that is very high or very low. Generally, absentee supervisors have deficient levels of leadership. Job performance is lower among employees who work for supervisors with low task leadership levels (McShane \& Glinow, 2010).

Leadership is a leader's behavior in managing, managing, and ordering his subordinates to do a task and the responsibilities they provide. A fun leader, nurturing, educating, and guiding will undoubtedly make employees happy with what his superiors command. This will undoubtedly be able to improve the performance of its employees (Kasmir, 2016). Research conducted by Rasool HF \& Arfeen IU (2015) aims to determine the effect (impact) of leadership style on employee performance in the Pakistani health sector. This study used a questionnaire of 334 samples, and the data obtained were analyzed using descriptive, regression, and correlation tests. One of the conclusions obtained in this study is that employee performance is affected by transformational leadership and transactional leadership.

Research conducted by Widodo (2006) on the influence of leadership style and job satisfaction on subordinates' performance. Using questionnaires in data collection and data testing using validity, reliability testing, multiple regression analysis. The results of the study are influential and significant leadership styles on company performance.

Research conducted by Putra \& Indrawati (2015) aims to determine the effect of transformational leadership, motivation, and work discipline on employee performance. The sample collection method used is a saturated sample, with 27 respondents. The data obtained were analyzed using validity, regression, and multiple regression analysis. The results of the study are transformational leadership has a positive effect on employee performance.

Based on the theory and logic of the results of previous studies, alternative hypotheses can be formulated: 
H3 : Charismatic leadership influences performance

\section{Training and Performance}

Training and development is a program given by the organization to each employee to develop skills, abilities, cooperation between employees, knowledge and solve problems in carrying out their work correctly (Jehanzeb \& Ahmed Bashir, 2013). Training and development provided by organizations aim to provide an organizational mission to trainees and support workers to understand the existing organization's culture (Jehanzeb \& Ahmed Bashir, 2013).

Training and development programs provided by organizations will improve their performance much better than employees who are not intrinsically motivated (Dysvik \& Kuvaas, 2008; Jehanzeb \& Ahmed Bashir, 2013; Sankey \& Machin, 2014).

Based on previous research explaining that employees will get many benefits from training and development programs, they will get the basic skills and technical skills needed in their jobs (Dobbs, in Jehanzeb \& Ahmed Bashir, 2013). Tillich (in Jehanzeb \& Ahmed Bashir, 2013) argues that most of the employees perceive the importance of training to improve performance and increase compensation. Training programs provided to employees will influence employee actions in workability and improve performance (Satterfield and Hughes, Jehanzeb \& Ahmed Bashir, 2013). Technical skills and professional skills are essential for employees to do their jobs more effectively (Barber, in Jehanzeb \& Ahmed Bashir, 2013). Therefore providing training and development programs for employees can improve employee performance (Jehanzeb \& Ahmed Bashir, 2013).

Based on the theory and logic of the results of previous studies, alternative hypotheses can be formulated:

H4: Training influences performance

\section{Self Efficacy and Performance}

Self-efficacy becomes more involved in their tasks and then, in turn, improves performance, which increases the efficacy even further. Changes in self-efficacy over time are related to creative performance changes (Robbins \& Judge, 2013).

Self-assessment of ability contributes to self-efficacy, but so does individual personality. Some people only have more confidence than others. Confidence in their ability to 
perform tasks effectively generates their confidence and can focus on performance. (Griffin \& Moorhead, 2014).

Self-efficacy is related to work performance, career choices, learning and achievement, and adapting to new technologies. Some training models can increase self-efficacy for trainees. A large-scale research study found that an individual with high self-efficacy tends to perform at a higher level. Also supporting this conclusion is Bandura and Locke's study, which found that individuals with high self-efficacy tend to exhibit higher levels of motivation and performance (Ivancevich et al., 2006).

Engko (2008) researched to examine the effect of job satisfaction on employee performance with self-esteem and self-efficacy as intervening variables. The data collection used a questionnaire of 43 samples from Gadjah Mada University Masters of Science students. The data obtained were analyzed using the classic assumption test. The results of the study include self-efficacy, which has a positive relationship with individual performance.

Research conducted by Liana, Rijanti, \& Herdiyanto (2016) aimed at analyzing the influence of motivation and self-efficacy on teacher performance moderated by transformational leadership styles in teachers of state junior high schools in Bojong Subdistrict, Pekalongan District. This type of research is field research with a quantitative approach. The data obtained were analyzed using multiple linear regression tests. One of the results of this study is that self-efficacy influences teacher performance.

Research conducted by Novianti (2016) aims to analyze the effect of self-efficacy on employee performance through PT's motivation. Coca-Cola Distribution Indonesia. This study uses a quantitative research approach that focuses on testing hypotheses. The statistical analysis used is Structural Equation Modeling (SEM). The results of the study are self-efficacy has a positive but not significant effect on employee performance.

Research conducted by Lai \& Chen (2012) about the relationship between self-efficacy, effort, performance, satisfaction, and employee turnover in

Taipei, Taiwan. This

the research uses Structural Equation Modeling (SEM). The results of this study are selfefficacy has a positive effect on performance 
Based on the theory and logic of the results of previous studies, alternative hypotheses can be formulated:

H5: Self Efficacy influences performance.

\section{Charismatic Leadership, Self Efficacy and Performance}

The motivational effect of charismatic leadership provides support for the role of self efficacy, "belief in one's ability to organize and carry out actions needed to produce certain achievements" (Bandura, 1997), in mediating the influence of charismatic leadership behavior on follower performance.

Research conducted by explaining that charismatic leaders enhance followers ' selfefficacy perceptions by communicating high performance expectations, expressing confidence in followers' ability to contribute to missions, and emphasizing the relationship between effort and important values. While conclusive empirical evidence supporting the role of self efficacy as a mediator in the relationship between charismatic leadership and follower performance is still lacking, some empirical work points in this direction.

Based on the theory and logic of the results of previous studies, alternative hypotheses can be formulated:

H6 : Self efficacy mediates the effect of charismatic leadership on performance

\section{Training, Self Efficacy, and Performance}

Research conducted by Suseno (2009) training is expected to give impetus to the formation of self-efficacy, namely the emergence of behavior that is influenced by perceptions of its performance abilities related to the results and value of the results obtained by someone.

According to Simamora (2006), employee performance refers to the level of achievement of the tasks that make up employees' work. If the employee has been given training, has good self-efficacy and employee engagement, the company expects them to produce a good performance.

Based on the theory and logic of the results of previous studies, alternative hypotheses can be formulated:

H7: Self efficacy mediating the effect of training on performance 
Based on the theoretical framework and previous studies, a theoretical framework can be developed to describe the relationship between variables. Self-efficacy and leadership as independent variables, performance as dependent variables, and motivation as media variables. So we get the following thoughts:

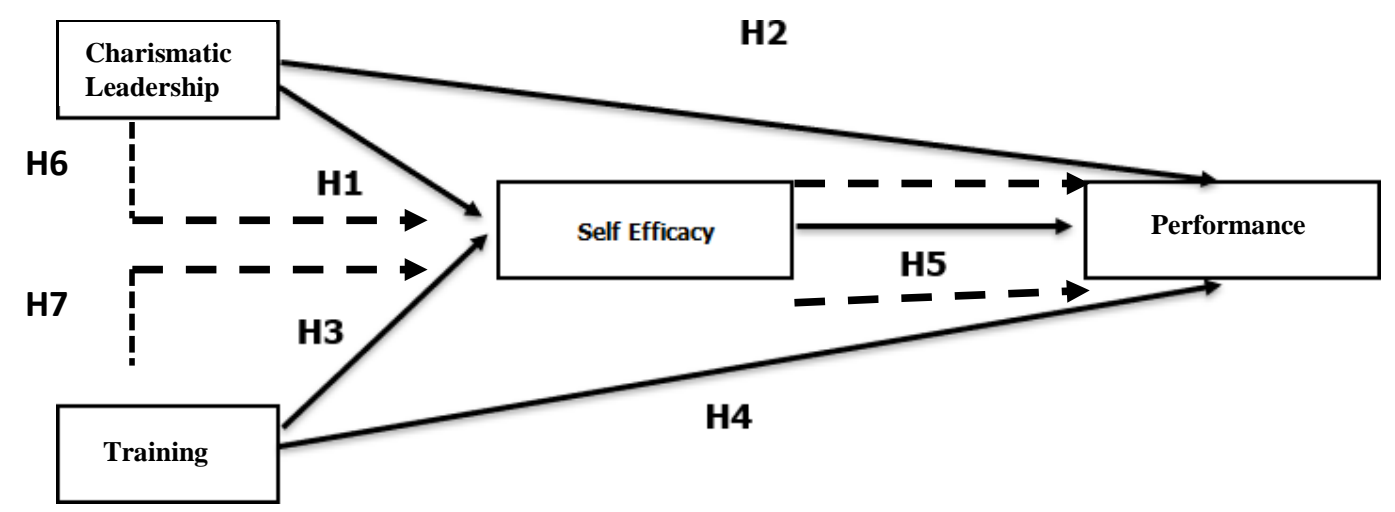

Figure 1. Research Model

\section{RESEARCH METHOD}

This study uses a quantitative approach. The object of this research is the performance of the Pushidrosal. Determination of the sample using the census method. The method used a survey method with a questionnaire and interview. The research design is descriptive, and the type of research used is explanatory research.

Data analysis methods used in this study include descriptive statistical analysis and parametric statistical analysis. Some analytical techniques used in this study include:

\section{Validity Test}

To determine the significance value is done by comparing the $\mathrm{r}$ arithmetic value with the $\mathrm{r}$ table with a degree of freedom $(\mathrm{df})=\mathrm{n}-1$. If $\mathrm{r}$ arithmetic is greater than $\mathrm{r}$ table and positive values, then the data or statement or indicator is declared valid (Ghozali, 2016; Sekaran \& Bogie, 2010).

\section{Data Reliability Test}

This study uses a reliability test with a one-shot or a one-time measurement. A constructor variable is said to be reliable if the Cronbach Alpha value $(\alpha)>0.7$ (Ghozali, 2016).

\section{Hypothesis Testing}


Testing the hypothesis in this study using Structural Equation Modeling (SEM). This study has a $95 \%$ confidence level with a tolerance value of $5 \%$.

The results of the conclusions in this study refer to indigo - p. If the p-value is greater than $5 \%$ error tolerance, then the analysis results accept the null hypothesis or reject the alternative hypothesis, then the results are not significant.

\section{RESULT AND DISCUSSION}

\section{Validity Test}

Testing the data's validity in this study using IBM SPSS 21 with Pearson correlation as a correction. This validity test is carried out to find out whether the items in the questionnaire are valid or not.

From the validity test, to determine the validity of invalid items in the questionnaire, it compares the value of $r$ arithmetic (Pearson) with the $r$ table. If the $r$ count (Pearson) is greater than the $r$ table and is positive, then the item is valid and can be used for research, and if the $r$ count (Pearson) is smaller than the $r$ table, then items that cannot be used in research (Ghozali, 2016). Based on the data processing results, the items used have a calculated r-value ( Pearson ) greater than the $r$ table so that these items can be used in this study.

\section{Reliability Test}

This study's reliability test uses IBM SPSS 21 with Cronbach Alpha $(\alpha)$ as a correction. A reliability test is used to find out the items used are consistent or stable over time. Data reliability test is done by one shot (one-time measurement). The data reliability test results can be seen in the following table:

Table 2. Data Reliability Test Results

\begin{tabular}{|l|l|l|l|}
\hline No & Variable & Crobach's Alpha (a) & Reliability \\
\hline 1 & Self Efficacy & .972 & Reliable \\
\hline 2 & Charismatic Leadership & 0.966 & Reliable \\
\hline 3 & Training & .958 & Reliable \\
\hline 4 & The performance & .958 & Reliable \\
\hline
\end{tabular}


Source: Primary Data Processed, 2019

A variable is said to have a high level of reliability if the Cronbach Alpha coefficient $(\alpha)>0.70$ (Ghozali, 2016). The variables used in this study were stated to be consistent or stable because each variable studied had a Cronbach Alpha $(\alpha)$ value greater than 0.07 . Overall Model Fit

The results of the overall model fit can be seen in the following table:

Table 3. Results Matches Size Model

\begin{tabular}{|c|c|c|c|}
\hline Criteria & $\begin{array}{c}\text { Cut of } \\
\text { Value (Value } \\
\text { Limits) } \\
\end{array}$ & $\begin{array}{c}\text { The } \\
\text { calculation } \\
\text { results } \\
\end{array}$ & Conclusion \\
\hline $\begin{array}{c}\text { Chi Square Statistics }\left(\mathrm{X}^{2}\right. \\
\text { ) } \\
\mathrm{P} .\end{array}$ & $\begin{array}{l}\text { Small value } \\
\mathrm{P} \leq 0.05\end{array}$ & $\begin{array}{l}1005,122 \\
P=0,000\end{array}$ & Poor fit \\
\hline \multirow[t]{3}{*}{ RMSEA } & RMSEA $\leq 0.08$ & \multirow[t]{3}{*}{0.086} & \multirow[t]{3}{*}{ Good fit } \\
\hline & $\begin{array}{c}0,08 \leq \text { RMSEA } \\
<0,10\end{array}$ & & \\
\hline & RMSEA $\geq 0.10$ & & \\
\hline \multirow[t]{3}{*}{ TLI } & $\mathrm{TLI} \geq 0.90$ & \multirow[t]{3}{*}{0885} & \multirow[t]{3}{*}{ Marginal fit } \\
\hline & $0.80 \leq \mathrm{TLI}<0.90$ & & \\
\hline & $\mathrm{TLI} \leq 0.80$ & & \\
\hline \multirow[t]{3}{*}{ IFI } & TLI $\geq 0.90$ & \multirow[t]{3}{*}{0887} & \multirow[t]{3}{*}{ Marginal fit } \\
\hline & $0.80 \leq \mathrm{TLI}<0.90$ & & \\
\hline & $\mathrm{TLI} \leq 0.80$ & & \\
\hline \multirow[t]{3}{*}{ CFI } & $\mathrm{CFI} \geq 0.90$ & \multirow[t]{3}{*}{0874} & \multirow[t]{3}{*}{ Marginal fit } \\
\hline & $0.80 \leq \mathrm{CFI}<0.90$ & & \\
\hline & $\mathrm{CFI} \leq 0.80$ & & \\
\hline CMIN / DF & $\mathrm{CMIN} / \mathrm{CF} \leq 5$ & 2,604 & Good fit \\
\hline
\end{tabular}

Source: Primary Data Processed, 2019

Based on Table 1.3 above, 2 GOF sizes show good fit matching, 3 GOF sizes that are marginal fit, and one size that shows poor fit. Therefore, the overall fit of the model in this study is a good fit. Based on these results, it can be concluded that the measurement model generally meets the suitability requirements, and it is decided to proceed with the interpretation of the estimation step. The following picture is a path diagram of the estimation results based on IBM AMOS 21 models. 


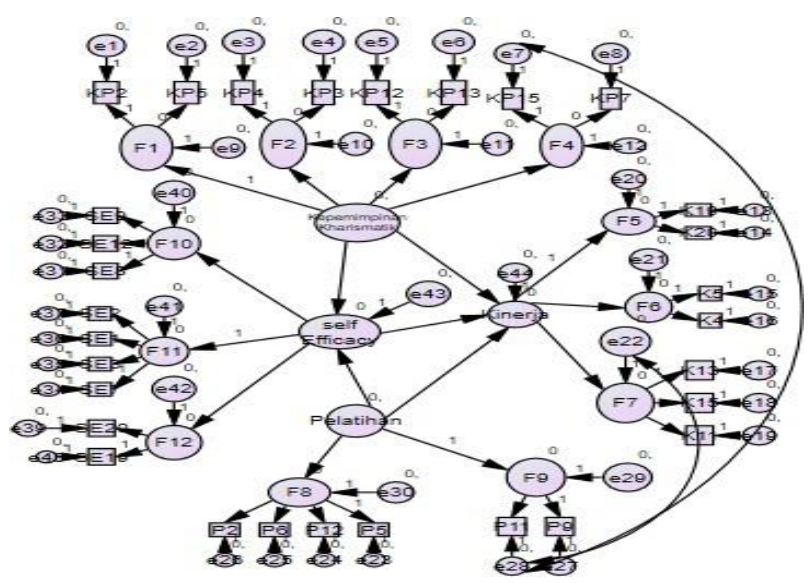

Figure 2. Results of Estimated Output Models

\section{Hypothesis Testing}

The structural model analysis is the relationship between parameters that show the effect of latent variables on other latent variables. Here is a table of regression weights and structural model research results.

Table 4. Regression Weights

\begin{tabular}{|lcc|lccr|}
\hline & & & Estimate & SE & CR & P. \\
\hline Self_Efficacy & $<---$ & $\begin{array}{l}\text { Charismatic } \\
\text { Leadership }\end{array}$ & $-0,117$ & 0.121 & $-0,968$ & 0.333 \\
Self_Efficacy & $<---$ & Training & $-0,111$ & 0.076 & -1.463 & 0.143 \\
The performance & $<---$ & Self_Efficacy & -0.01 & 0.049 & -0.205 & 0838 \\
The performance & $<---$ & Training & 0.21 & 0.051 & 4,075 & $* * *$ \\
The performance & $<---$ & $\begin{array}{l}\text { Charismatic } \\
\text { Leadership }\end{array}$ & 0.473 & 0.12 & 3,949 & $* * *$ \\
\hline
\end{tabular}

Source: Primary Data Processed, 2019

Based on the table above, the hypothesis obtained is as follows:

Table 5. Results of Structural Model Analysis

\begin{tabular}{|l|l|c|l|}
\hline Hypothesis & \multicolumn{1}{|c|}{ Path } & P. & \multicolumn{1}{c|}{ Conclusion } \\
\hline H1 & $\begin{array}{l}\text { Charismatic Leadership } \\
\rightarrow \text { Self Efficacy }\end{array}$ & .333 & Hypothesis Rejected \\
\hline H2 & Training $\rightarrow$ Self Efficacy & .143 & Hypothesis Rejected \\
\hline
\end{tabular}




\begin{tabular}{|l|l|l|l|}
\hline H3 & $\begin{array}{l}\text { Charismatic Leadership } \rightarrow \\
\text { Employee Performance }\end{array}$ & 0,000 & Hypothesis Accepted \\
\hline H4 & $\begin{array}{l}\text { Training } \rightarrow \text { Employee } \\
\text { Performance }\end{array}$ & 0,000 & Hypothesis Accepted \\
\hline H5 & $\begin{array}{l}\text { Self Efficacy } \rightarrow \text { Employee } \\
\text { Performance }\end{array}$ & 0.838 & Hypothesis Rejected \\
\hline
\end{tabular}

Source: Primary Data Processed, 2019

Table 1. 6 Results of Sobel Test Calculation Analysis

\begin{tabular}{|l|l|l|l|}
\hline Hypothesis & \multicolumn{1}{|c|}{ Path } & \multicolumn{1}{|c|}{ Sobel Test } & probability \\
\hline H6 & $\begin{array}{l}\text { Charismatic Leadership } \rightarrow \text { Self } \\
\text { Efficacy } \rightarrow \text { Performance }\end{array}$ & 6,18924 & 0,000 \\
\hline H7 & $\begin{array}{l}\text { Training } \rightarrow \text { Self Efficacy } \rightarrow \\
\text { Performance }\end{array}$ & 2.81925 & 0.00481 \\
\hline
\end{tabular}

Source: Primary Data Processed, 2019

In testing the hypothesis will be accepted if the regression weights $<0.05$.

\section{Analysis of the Interpretation of Research Hypotheses}

The analysis of measurement models in the study showed that all variables had met the data's validity and reliability criteria. In testing the structural model analysis, all hypotheses support the proposed hypothesis. The interpretation analysis for each hypothesis is as follows:

1) The results of the test of the charismatic leadership influence on soldier selfefficacy.

The results of this study's charismatic leadership did not influence the selfefficacy of Pushidrosal soldiers. This is due to the lack of sensitivity of the leader to the belief held soldier. This is evidenced by the respondent's answer to the lowest indicator with an average point of 3.64 'I have a complaint that the leader listens to". This is in line with Mesterova's (2015) study conducted at Czech universities, which explains that leadership does not affect self-efficacy. This means that even though the leadership style of the military environment is firm, the leader must still listen to any input and suggestions and the complaints felt by 
subordinates so that the soldiers can feel the charismatic leadership style of their leaders. Soldiers will feel heard, and the morale of soldiers will rise.

2) Test Results of the effect of training on soldier self-efficacy.

The results of this research training did not affect the self-efficacy of Pushidrosal soldiers. This is due to the less effective training methods given to soldiers. This is evidenced by the respondent's answer to the lowest indicator with an average point of 4.06, "I get a good training method from the trainer," with the lowest value assumed that few soldiers understand the training methods given to him. This is in line with research Earley (1994), Richaerd, Diefendorff, \& Martin (2009), and Vancouver, Thompson, \& Williams (2001) explain that inadequate training does not affect self-efficacy. This means that training materials provided to soldiers must be on target following their respective fields of expertise. However, often the training that is carried out will not be practical if the training is not following the soldier's duties.

3) Test Results of the influence of charismatic leadership on soldier performance. The results of this charismatic study leadership affect the performance of Pushidrosal soldiers. A fun, nurturing, educating, and guiding leader will undoubtedly make employees happy with what his superiors command. This will undoubtedly be able to improve the performance of its employees (Kasmir, 2016). This means that the leader encourages employees to want to, listens to complaints felt by employees, and instills vision to employees. Employees are responsible for the tasks given by the leader, rarely absent or absent, and can coordinate with colleagues so that the employee's performance is good.

This is in line with studies conducted by Cavazotte, Moreno, \& Bernardo (2013) on employees in Brazil, Wiyatmini and Luqman (2008) at the Depok City Health Office, Slamet Ruyadi (2011) in Manufacturing Companies in East Java, Putra \& Indrawati (2015) in CV Motor Agung I of Tabanan Regency, Tampubolon, (2007) in Organizations that have implemented SNI 19-9001-2001, Rasool HF, Arfeen IU (2015) in the Health sector of Pakistan, Sougui, Bon, Mohamed, \& Hassan (2016) in the Telecommunications Engineering Company. This means that the charismatic leadership style of a leader is increasingly seen by protecting, giving 
guidance, direction, and a whole spirit like a respected father will be able to increase the motivation of his soldiers and will be able to have a good effect on performance so that it can be concluded that charismatic leadership influences on soldier performance. So it can be concluded that charismatic leadership influences the performance of soldiers.

4) Test Results of the effect of training on soldier performance.

The results of this research training affect the performance of Pushidrosal soldiers. With training, the soldier will get better and on time in completing the work given to him. Work that can be completed correctly and on time will indirectly improve the performance of the soldier. This is in line with previous research explaining that employees will get many benefits from training and development programs; they will get the basic skills and technical skills needed in their work (Dobbs, in Jehanzeb \& Ahmed Bashir, 2013). Tillich (in Jehanzeb \& Ahmed Bashir, 2013) argues that most of the employees perceive the importance of training to improve performance and then increase compensation. Training programs provided to employees will influence employee actions in workability and improve performance (Satterfield and Hughes, in Jehanzeb \& Ahmed Bashir, 2013). This means that training materials that are right on target and in accordance with their main duties and functions will affect the performance of Pushidrosal Soldiers. S.

5) Test Results of the effect of self-efficacy on soldier performance

The results of this study are that self-efficacy does not affect the performance of Pushidrosal soldiers. This is due to the fact that the soldiers have not yet corrected the work done. This is evidenced by the respondent's answer to the lowest indicator with an average point of 3.56, "I corrected the work carefully," with the lowest average value; it is assumed that few soldiers corrected their work before being handed over to the leadership. This is in line with research conducted by Prasetya et al. 1 (2013) of Accounting Lecturers at the Residency of Madiun, Kaseger (2013) at PT. Matahari Department Store Manado Town Square states that self-efficacy does not affect performance. This means that it can be concluded that self-efficacy does not affect the performance of Pushidrosal soldiers. 
6) The results of the test of the mediating role of self-efficacy in the influence of charismatic leadership on soldier performance.

The results of this study are self-efficacy plays a role in mediating the influence of charismatic leadership on performance. Charismatic leadership can increase the efficacy of the soldiers. With the increase in the efficacy/confidence in the soldier to complete his work, his performance will also increase. This is in line with the theory of Bandura (1997), which states that the motivational effects of charismatic leadership provide support for the role of self-efficacy, "belief in one's ability to organize and carry out the actions needed to produce specific achievements, in mediating the influence of charismatic leadership behavior on follower performance.

7) Test Results of the mediating role of self-efficacy in the effect of training on Pushidrosal soldiers' performance.

This study's results are that self-efficacy mediates the effect of training on the performance of Pushidrosal soldiers. With training, the soldier will feel confident in his ability to complete his work. Confidence in the ability to complete the work will increase the efficacy of him. With the increased efficacy in him, the performance of the soldier himself. This is in line with research conducted by Suseno (2009), Halper, Vancouver, \& Bayes (2018), and Behrooz et al. (2018) explain that training is expected to provide the impetus for the formation of selfefficacy, namely the emergence of behavior that is influenced by the perception of the ability of performance related to the results and the value of the results obtained by someone.

\section{CONCLUSION}

1) Charismatic leadership that is getting better does not have a direct and significant effect on self-efficacy.

2) Increasingly, training does not have a direct and significant effect on self-efficacy.

3) Charismatic leadership shown by superiors has a positive and significant effect on performance. 
4) Training with the proper method and intensity has a positive and significant effect on performance.

5) Self-efficacy is high, not direct, and significant impact on the performance of soldiers.

6) Self-efficacy has a positive mediating role in the effect of training on soldier performance.

7) Self-efficacy has a positive mediating role in the influence of charismatic leadership on soldier performance.

\section{Implication}

Theoretical Implications

1) Charismatic leadership has no direct and significant effect on self-efficacy. This is in line with Mesterova's (2015) study conducted at Czech universities.

2) Training has no direct effect on self-efficacy. This is in line with research by Earley (1994), Richaerd, Diefendorff, \& Martin (2009), and Vancouver, Thompson, \& Williams (2001).

3) Charismatic leadership has a positive and significant effect on performance. This is in line with studies conducted by Cavazotte, Moreno, \& Bernardo (2013), Wiyatmini and Luqman (2008), Slamet Ruyadi (2011), Putra \& Indrawati (2015), Tampubolon (2007), Rasool HF, Arfeen IU (2015), Sougui, Bon, Mohamed, \& Hassan (2016).

4) Training has a positive and significant effect on performance. This is in line with Dobbs' research, in Jehanzeb \& Ahmed Bashir ( 2013), Tillich, (in Jehanzeb \& Ahmed Bashir, 2013) (Satterfield and Hughes, in Jehanzeb \& Ahmed Bashir, 2013).

5) Self-efficacy has no direct and significant effect on performance. This is in line with research conducted by Prasetya et. (2013), Kaseger (2013).

6) Self-efficacy has a positive mediating role in the influence of charismatic leadership on performance. This is in line with the theory of Bandura (1997).

7) Self-efficacy has a positive mediating role in the effect of training on performance. This is in line with research conducted by Suseno (2009), Halper, Vancouver, \& Bayes (2018), and Behrooz et al. (2018). 
Managerial Implications

1) A leader needs to prioritize the family aspect to make a place to convey aspirations and complaints about his soldiers.

2) Institutions can evaluate whether the training given to service members has benefited current and future institutions. Institutions can research other institutions to find this out, so institutions can arrange new training if institutions' training is lower than similar institutions.

3) Good charismatic leadership will improve soldier performance. Institutions need to be led by a charismatic person who can protect, guide, and be firm with work.

4) Institutions can make training plans to further serve as career development that can promote promotions and ranks so that they directly influence the soldiers ' self-efficacy.

5) The leader can give the task to the soldier by giving an example first or a bright picture so that it can be done well.

6) A charismatic leader will give satisfaction to the soldiers.

7) Career development and good training will give satisfaction to soldiers, so that it will affect the performance and course of the organization because soldiers already feel satisfaction in their careers.

Suggestion

1) A charismatic leader must listen to subordinates' input suggestions so that subordinates feel their views and aspirations will be accommodated by carrying out continuous briefings (carrying out commander hours) and thoroughly so that the leadership can know every subordinate's input and aspirations.

2) The intensity and accuracy of the training material provided by the field of expertise and work in the field of surveying and mapping start from the base are tiered and continues according to the stages, so soldiers will be increasingly trained to affect performance.

3) The charismatic leadership style of a leader who is always highlighted will increase the motivation of his soldiers. It will be able to have a good effect on performance, such as promoting family attitudes and assuming subordinates are an inseparable part. 
4) The method or material provided to the soldier must be effective and regarding the target by the area of expertise of the soldier. Therefore, selecting the types of training material that is appropriate to the area of their daily duties is needed so that if the training material and intensity are appropriate, then the soldier's confidence arises. Will be able to carry out daily tasks, such as ArcGIS training at basic and advanced levels that have not been carried out as a total capital for positioning at sea that all soldiers should know, training in navigation news making, and others.

5) The behavior or behavior of soldiers who do not care or correct the results of work that has been completed so requires extra personnel to repeat the work for that institution to discipline soldiers more by providing extra supervision of the work and daily activities by making a journal or task schedules to be further checked and signed by superiors, to minimize errors that exist.

6) Institutions are more able to motivate their employees so that employees are more motivated both internally and externally so that soldiers will be able to go through a training program well if each individual feels that the institution's training program is what they need. Soldiers are given a certification of worthiness and given appreciation to increase the soldiers' confidence and confidence to complete the work; the performance will automatically increase.

7) There is training to feel equipped with the knowledge and are confident in their ability to complete work. Confidence in the ability to complete the work will increase the efficacy. In determining the trainer or instructor, it is suggested that the institution can consider and or choose a coach who is more competent in the field that will be used as a training program. Trainers can be from internal qualifications, trainers from outside institutions, namely academics, training centers, and bring in from abroad.

\section{References}

Achua, C., F. and Lussier, R., N. 2010. Effective leadership. South Western: Delmar Cengange Learning 
Ackah, D. (2014). The Impact of Motivation on Employee Performance in the Manufacturing Industry in Ghana. Global Journal of Management Studies and Research , 1 (5), 291-310.

Antonioni, D. 1996. Designing an Effective 360-Degree Appraisal Feedback Process. Organizational Dynamics, Autumn: 24-38.

Bass, B., \& Avolio, B. (1994), Improving organizational effectiveness through transformational leadership . Thousand Oaks, CA: Sage Publications

Bernardin, H. John. \& Rusell, JEA (2003). Human Resources Management. New York : Mc Graw Hill Inc.

Colquitt, Jason A., Jefery A. Lepine \& Michael J. Wesson. (2015). Organizational Behavior Improving Performance and Commintment in the Workplace 4th Edition . 2015: McGraw Hill Education.

Decramer, A., Smolders, C., \& Vanderstraeten, A. (2013). Employee performance management culture and system features in higher education: relationship with employee performance management satisfaction. International Journal

Delbecq, A., House, R., J., Luque., M., S., D., Quiegley., N., R. Implicit Motives, Leadership, and Follower Outcomes: An Empirical Test of CEOs. Journal of Leadership \& Organizational Studies, Vol. 20. No.1

Dysvik, A., \& Kuvaas, B. (2008). The relationship between perceived training opportunities, work motivation and employee outcomes. International Journal of Training and Development, 12 (3), 138-157.

Earley, PC (1994). Self or Group? Cultural Effects of Training on Self-Efficacy and Performance. Administrative Science Quarterly , 39 (1), 89.

Engko, C. (2008). Effect of Job Satisfaction on Individual Performance with Self Esteem and Self Efficacy as Intervening Variables. Business and Accounting , 10 (1), 1-12.

Ghozali, Imam. (2016). Multivariate Analysis Application with IBM SPSS 23. Semarang Program : Diponegoro University Publisher Agency.

Gist, Marlyin E. (1989). The Influence Of training methods on self efficacy and the idea of generatin emong managers. Personael Pyscology.

Hair, JF, Black, WC, Babin, BJ, \& Anderson, RE (2010). Multivariate Data Analysis (7th ed.). New Jersey: Prentice Hall. 
Hartono M, J. (2004). Incorrect Business Research Methodology and Experiences (6th ed.). Yogyakarta: BPFE Yogyakarta.

Ilyas, Y. (2001). The performance. Theory, Assessment, and Research . Center for Health Economics Studies. Faculty of Public Health. University of Indonesia. Jakarta

Ivancevich, John. M., Robert Konopaske \& Michael T. Matteson. (2006). Organizational Behavior and Management. Seventh Edition. Translated by: Gina Gania. Jakarta: Erlangga.

Jehanzeb, K., \& Ahmed Bashir, N. (2013). Training and Development Program and its Benefits to Employees and Organizations: A Conceptual Study. European Journal of Business and Management, 5 (2), 2222-2839.

Jodlbauer, S., Selenko, E., Batinic, B., \& Stiglbauer, B. (2012). The relationship between job satisfaction and training transfer. International Journal of Training and Development , 16 (1), 39-53.

Cashmere. Human Resource Management (Theory and Practice) . (2016). Jakarta: Raja Grafindo Persada.

Kreitner, Robert \& Angelo Kinicki. Organizational Treatments Organizational behavior. (2004). 9th edition . Translated by: Alchemist Language Bureau. Jakarta: Salmeba Empat.

Lai, M., \& Chen, Y. (2012). Self-Efficacy, Effort, Job Performance, Job Satisfaction, and Turnover Intention: The Effect of Personal Characteristics on Organizational Performance. International Journal of Innovation, Management and ... , 3 (4), 387391.

Liana, L., Rijanti, T., \& Herdiyanto. (2016). The Effect of Motivation and Self Efficacy on Teacher Performance Moderated by Transformational Leadership Styles (Study of State Junior High School Teachers in Bojong District, Pekalongan Regency). In Proceedings of the Multi- Disciplinary National Seminar Seminar \& Call For

Luthans, Fred, Organizational Behavior and Evidence based approach, 12 Edition New York. McGraw Hill, 2011.

Mathis, Robert L. \& John H. Jackson. 2010. Human Resources Management 13th Edition: South- Western Cengage Learning 
McShane and Von Glionw, 2010. Organizational Behavior emerging knowledge and practice for the real world (New York: McGraw Hill.

Mitzberg, H. (2008). Personnel Management . Jakarta: Erlangga.

Novianti, D. (2016). The effect of self-efficacy on employee performance with motivation as an intervening variable (study of employees of the finance division and the human resource division of PT. Coca-Cola Distribution Indonesia, Surabaya). Journal of Management Sciences , 4 , 1-12.

Pansari, A., \& Kumar, V. (2015). Measuring the Benefits of Employee Engagement Measuring the Benefits of Employee Engagement, 56 (4).

Peng, J., \& Quan, J. (2012). Characteristics of Social Networks and Employee Behavior and Performance: A Chinese Case Study of a, 25 (4), 26-45.

Prawirosentono, S. (2008). Human Resources Management Employee Performance Policy. Yogyakarta: BPFE.

Putra, I. wayan, \& Indrawati, A. (2015). The Influence of Transformational Leadership, Motivation and Work Discipline on Employee Performance in Cv. Agung Motor I in Tabanan Regency. Eud Management E-Journal , 4 (10), 2982-3011. Rasool HF, Arfeen IU, MW \& AU (2015). Leadership Styles and Its Impact on Employee'S Performance in the Health Sector of Pakistan. City University Research Journal , 5 (1).

Richard, EM, Diefendorff, JM, \& Martin, JH (2009). Citizenship Performance Transformational Leadership, Job Characteristics, and Organizational Citizenship Performance. Online , 9285 (907681676), 37-41.

Robbins, Stephen P., Timothy A. Judge, 2015. Organizational Behavior 16 Edition. England: Pearson, Organizational Behavior and Evidence based approach, $12 \mathrm{New}$ York Edition, Mc Graw Hill,

Sankey, KS, \& Machin, MA (2014). Employee participation in non-mandatory professional development - the role of core proactive motivation processes. International Journal of Training and Development , 18 (4), 241-255.

Sekaran, U., \& Bougie, R. (2010). Research Methods for Business: A Skill Building Approach (5, illustrated.). John Wiley \& Sons. 
Shamir, B., House, RJ, and Arthur, MB 1993. The Motivational Effects of Charismatic Leadership: Self- Concept Based Theory. Organization Science, Vol 4 No. 4

Suseno, Miftahun Mi'mah. (2009). The Effect of Interpersonal Communication Training As Self- Efficacy As A Training For Students. Journal of Psychological Interventions . Vol 1 (1)

Suyadi Prawirosentono. (2008).HumanResources Management Employee Performance Policy. Yogyakarta: BPFE.

Towler, A., Watson, A., \& Surface, EA (2014). Signaling the importance of training, 29 (7), 829-849. Vancouver, JB, Thompson, CM, \& Williams, AA (2001). The Changing Signs in the Relationships

Among Self-Efficacy, Personal Goals, and Performance . 86 (4).

Wagen, Lynn Van der. 2007. Human Resource Management for Events managing the event workforce. Oxford: Events Management Series

Wardani, Deta Shinta Kusuma (2012). Effect of Effective Communication Training to Improve Student Self-Efficacy. Journal of Educational Psychology and Development Vol. 1 No. 02.

Weber, J. (2015). Investigating \& Assessing the Quality of Employee Ethics Training Programs Among US-Based Global Organizations. Journal of Business Ethics , $129,27-42$.

Widodo, U. (2006). Analysis of the Effect of Leadership Style and Job Satisfaction on Subordinate Performance (Empirical Study of Private Universities in the City of Semarang. Economic Focus, 1 (2). 